\title{
The Construction of Innovative Education Curriculum System for High School Students: Based on the Practice of "Workshop + Project" Innovative Education Curriculum of Zhengzhou No. 12 Middle School, China
}

\author{
Hongxun Zhang \\ Zhengzhou No. 12 Middle School, Zhengzhou 450000, Henan, China
}

\begin{abstract}
Innovative education is a higher training requirement for education in the period of social transformation. It needs the education to cultivate talents with innovative consciousness and ability for the development of society. High school is critical for facilitating students' innovative consciousness, innovative thinking, and innovative ability development. Aiming at the problems of insufficient resources, fragmentation of education, and simplification of evaluation in the current practice of innovative education, Zhengzhou No.12 Middle School integrates the characteristics of maker education and STEAM education to carry out the top-level selection, training, evaluation, and development of innovative talents. Formed an innovative education curriculum system that takes "Workshop + Project" as the starting point, relies on research learning courses, multi-dimensional evaluation as a guarantee, and integrates classroom teaching, club activities, project research, intellectual property rights, and expert guidance.
\end{abstract}

Science Insights Education Frontiers 2021; 9(2):1265-1281.

Doi: 10.15354/sief.21.or044

How to Cite: Zhang, H. (2021). The construction of innovative education curriculum system for high school students: Based on the practice of "workshop + project" innovative education curriculum of Zhengzhou No. 12 Middle School, China. Science Insights Education Frontiers, 9(2):1265-1281. 
Zhang. Innovative Education Curriculum System for High School Students.

Keywords: Innovative Education, Innovative Courses, High School, "Workshop + Project", Pathway

Correspondence to: Hongxun Zhang, Research Director, Zhengzhou No. 12 Middle School, Zhengzhou, 450000, Henan, China. E-mail: zhx630@139.com

Conflict of Interests: None.

(C) 2021 Insights Publisher. All rights reserved.

cc) (i) (-) Creative Commons Non Commercial CC BY-NC: This article is distributed under the terms of the Creative Commons Attribution-NonCommercial 4.0 License (http://www.creativecommons.org/licenses/by$\mathrm{nc} / 4.0 /$ ) which permits non-commercial use, reproduction and distribution of the work without further permission provided the original work is attributed by the Insights Publisher. 
$\mathrm{T}$ HE transformation of the social economy from the traditional industrial economy to the knowledge economy means that innovation, the essential feature of the knowledge economy, appears to be very important. The American Austrian economist Joseph, known as the originator of "innovation theory," first proposed the concept of innovation in the book "The Theory of Economic Development" (Schumpeter, 1934). According to Joseph, the so-called innovation is to "establish a new production function." In other words, a new combination of factors of production and production conditions that have never been used is introduced into the production system. The innovative concept proposed by Joseph mainly focuses on the technical level. However, with the continuous development of the connotation and extension of the concept of innovation, all activities that can improve the efficiency of resource allocation are innovations.

Innovative education is based on constructivist learning theory and multiple intelligence theory, with the fundamental value orientation of cultivating people's innovative spirit and ability. The core is to cultivate students' exploration spirit of "rediscovering" knowledge through various forms of school education, facilitating the comprehensive power of "recombining" knowledge and the creative consciousness and ability to prepare for "first and unprecedented" things.

As an essential component of basic education, high school is critical for students' personality development and awakening innovative consciousness. Supplementing and accumulating innovative knowledge at this stage and stimulating students' innovative and creative thinking is of great significance to cultivating students' creative ability. In terms of high school education, it is essential to build an innovative education curriculum system and develop high-quality, innovative talents under innovative ideas.

In the exploration and practice of innovative education curriculum construction, Zhengzhou No. 12 Middle School used project research as a carrier, with a maker workshop as a position, appointed professional teachers, and compiled professional teaching materials. The teaching materials were included in the class schedule, allowing the workshop to enter the classroom, forming an innovative, maker education training model that integrated classroom teaching, club activities, project research, intellectual property rights, and expert guidance. This has promoted the normalization of high schools to carry out new ideas and new ideas of innovative education and formed the school's innovative education characteristics. In addition, it has become a model for the new curriculum reform in Henan Province. Therefore, we researched the exploration and practice of "Workshop + Project" launched by Zhengzhou No. 12 Middle School to promote the construction of maker education courses.

\section{Maker Education, STEAM Education, and Innovative Education}

Maker education is believed to have originated in the Fab Lab (Fabrication Laboratory) initiated by the Center for Bits and Atoms of the Massachusetts Institute of Technology (MIT) in 2001. On this basis, a user-centered application innovation platform has been 
built. As a result, the main body of innovation has expanded from the original scientific research and technical personnel to the general public, and the "Maker Culture" has gradually emerged. In 2009, US President Barack Obama published a famous initiative on "A Nation of Makers" at the "Educate to Innovate" conference. This initiative has enabled Maker Education, which has implemented the educational ideals of famous educators such as Piaget, Dewey, and Papert, to attract more and more researchers' attention (Office of the Press Secretary, 2009). Subsequently, the White House also immediately launched the "Maker Education Initiative" (MEI). Vigorously promote the development of maker education in primary and secondary schools and colleges (Kalil, 2015). Maker Education recognizes the value of "learning by doing" based on Dewey's "school is society, education is life" philosophy (Shapiro, 2016). It aims to provide students with a suitable environment, resources, and opportunities for creation, especially with the help of Network technology tools and open source software (such as 3D printers, Arduino, etc.) allow students to cultivate critical thinking and innovative thinking by integrating creative-based learning. Further, improve the quality of education, develop students' self-confidence, creativity, and interest in science, technology, engineering, mathematics, art, etc., and make them effective innovation carriers (Maslyk, 2018).

STEAM education, which originated in the United States, is also widely recognized worldwide for its interdisciplinary, experiential, technical, and collaborative nature. In 2001, Judith Ramaley, Deputy Chairman of the Education and Human Resources Council, National Science Foundation of United States, used the term STEM (an acronym for science, technology, engineering, and mathematics) for the first time in curriculum development. Its purpose is to advocate interdisciplinary science education driven by problem-solving so that those future talents can adapt to the level of globalization of the knowledge economy and the trend of increasing complexity and cooperation (Hallinen, 2020). After decades of development, STEM education is being carried out with different courses or activities in schools of different stages in more countries outside the United States. For example, in 2011, the Ministry of Education, Science, and Technology of South Korea added humanities to the STEM curriculum model and formed the STEAM curriculum model.

It can be seen that maker education and STEAM education are both innovative education. Both are specific methods and approaches to implement innovative education, but there are also some differences. STEAM education is developed around the knowledge and ability of science, technology, engineering, mathematics, and art, focusing on improving students' STEAM literacy, optimizing academic performance, and laying the foundation for the growth of innovative talents (Teng et al., 2019). On the other hand, the proposal of maker education began with the development of the maker movement, aiming to reshape education by applying maker ideas. It emphasizes turning creative ideas into real works through hands-on operation and learning in creation (He, 2016). Compared with STEAM education, maker education is more directly directed to innovative education, with a more explicit purpose and implementation path. Therefore, maker education and STEAM education integration can bring epoch-making changes to 
the current comprehensive practical courses and information technology courses in basic education and jointly promote innovative talents (Yang, 2016).

Of course, innovative education is a complex system engineering that requires the coordinated operation of various educational forms. Therefore, in addition to maker education and STEAM education, moral education and traditional culture education are also essential forms and foundations for promoting innovative education.

\section{Problems in the Development of Innovative Education in China}

China also regards the development of innovative talents as a new national development strategy in the 21 st century. In 2010, the State Council government issued the "Outline of China's Medium and Long-term Educational Reform and Development Plan (20102020)", which put forward efforts to train hundreds of millions of high-quality workers, thousands of specialized talents, and a large number of top-notch innovative talents (The Office of the Working Group of the National Medium and Long-term Education Reform and Development Plan Outline, 2010). High school education is a critical period for forming an independent development of a student's personality and has special significance for improving the nation's quality and cultivating innovative talents. The curriculum is the core of school education. Therefore, to develop the curriculum's innovative spirit and practical ability, we must start with curriculum reform.

In 2016, the Chinese government incorporated innovative education and courses into the "Thirteenth Five-Year Plan for Education Informatization." It also requires regions with conditions to actively explore the application of information technology in new education models such as "crowd creation space," interdisciplinary learning (STEAM education), and maker education. We must make efforts to improve students' information literacy, innovation awareness, and innovation ability. Develop digital learning habits and promote the overall development of students. It is necessary to give play to the supporting and leading role of informatization in cultivating high-quality talents in the future (MOE, 2016).

In 2018, the Ministry of Education issued the High School Curriculum Standards for Various Subjects (2017 Edition). STEAM, STEM, and STEM+ education appear in the curriculum standards of multiple related subjects (MOE, 2018). "Technology and Humanities Integration and Innovation Topics" in the optional compulsory module of "High School General Technical Curriculum Standards" under the "Technology and Innovation" module, mention the extensive use of science, technology, engineering, art, mathematics, society (from now on referred to as STEAMNS) and other disciplines Knowledge, methods and skills. It is proposed to carry out problem solving and technological innovation in topic learning or project learning. This module aims to help students form a vision of subject integration to comprehensively use multi-disciplinary knowledge and methods to systematically analyze and solve real-world scientific, technical, and engineering problems (MOE, 2017). 
However, in cultivating students' innovative spirit, Chinese high schools face many problems promoting creative education courses. For example, Guo (2000) pointed out that although innovative education in middle school classroom teaching pays attention to process teaching, the guidance of innovative learning methods is insufficient. As a result, no matter in textbook excavation or teacher-student interaction, students' creative thinking cannot be intensely cultivated. Li \& Wang (2014) also pointed out that school education tends to rush for quick success and instant profit under the existing examination-oriented education system, obliterating students' creativity.

Specifically, the main problems are as follows:

(i) Insufficient practical resources. Innovative education is different from the usual knowledge understanding education. It must be based on practice, and the biggest problem encountered at the beginning of implementation is precisely the lack of resources such as venues, tools, and equipment.

(ii) Fragmentation of innovative education. Innovative education has been carried out under various names, but the problem of fragmentation is more prominent. There is no unified target design, no comprehensively designed innovative curriculum system, scattered and random, lacking integration and overall design.

(iii) Simplified evaluation of innovation achievements. Evaluation is the driving force for the implementation of innovative education. However, the traditional way of evaluating results is usually to compare the results. This lacks scientific and institutional nature and cannot effectively motivate students to participate in innovative curriculum activities.

\section{Measures to Promote Innovative Education Reforms in High Schools}

To solve insufficient resources, fragmented education, and simplified evaluation, Zhengzhou No. 12 Middle School is based on student development. It integrates the characteristics of maker education and STEAM education. We have organized different project research groups according to students' hobbies and expertise to meet the psychological needs of all students for personality development and stimulate students' curiosity and desire for exploration in many ways. At the same time, based on diversified project groups, the school builds practical operation research sites and production spaces to provide a platform for students' practical exploration. After years of practice, a maker education curriculum and practice system of "Workshop + Project" to promote innovative education have been formed, including scene resources, creative courses, and an evaluation system (Table 1).

\section{Build Six “Workshop" Platforms that Support the In- novative Curriculum System}


Table 1. Evaluation Dimensions and Contents.

\section{Evaluation \\ Dimension \\ Activity Attitude \\ Evaluation}

\section{Evaluation Content}

The initiative and enthusiasm of students in research activities can be evaluated by the time, frequency, seriousness, and behavior of students participating in activities. For example, whether students take the initiative to participate in each themed activity, take the initiative to propose ideas and suggestions, carefully observe and think about the problem, actively use their brains, carefully search for relevant materials, complete the study plan on time, not be afraid of difficulties, and insist on completing tasks.

\begin{tabular}{|c|c|}
\hline $\begin{array}{l}\text { Evaluation of the } \\
\text { Spirit of Coopera- } \\
\text { tion }\end{array}$ & $\begin{array}{l}\text { It mainly evaluates the cooperative attitude and behavior of students in participat- } \\
\text { ing in group and class activities. Such as whether students actively participate in } \\
\text { group activities, take the initiative to help others, seek help from others, listen } \\
\text { carefully to classmates' opinions, share results with others, and take the initiative } \\
\text { to play their role in the group. }\end{array}$ \\
\hline $\begin{array}{l}\text { Evaluation of } \\
\text { Inquiry Ability }\end{array}$ & $\begin{array}{l}\text { It can be evaluated by students' performance in asking and solving problems and } \\
\text { their expression of the inquiry results. For example, whether students dare to ask } \\
\text { questions, start to solve the issues, and express their learning results in a unique } \\
\text { and novel way, whether they are good at observing and recording, can compre- } \\
\text { hensively use relevant information, actively adopt a variety of methods, and ex- } \\
\text { press their learning process vividly and the result. }\end{array}$ \\
\hline $\begin{array}{l}\text { Social Practice, } \\
\text { Communication } \\
\text { Ability Evaluation }\end{array}$ & $\begin{array}{l}\text { It can be evaluated by the students' ability to communicate with others, the skills, } \\
\text { and desires of communicating and cooperating with others, and coordinating vari- } \\
\text { ous relationships. }\end{array}$ \\
\hline $\begin{array}{l}\text { Evaluation of the } \\
\text { Ability to Collect } \\
\text { and Process Infor- } \\
\text { mation }\end{array}$ & $\begin{array}{l}\text { It can be evaluated by the amount, methods, ways, authenticity of students' col- } \\
\text { lection of information, as well as their ability to discern and reflect on the infor- } \\
\text { mation and to respond. }\end{array}$ \\
\hline
\end{tabular}

The school integrates various resources within the school and strives to build a maker workshop of more than 570 square meters. It consists of six parts: information retrieval center, project research and design room, robotics studio, mathematics inquiry laboratory, production space, and science laboratory. Designated teachers are in charge of the Maker Workshop, and regular classes are held to become a paradise for students' innovation and creativity.

\section{- Information Publishing and Retrieval Center}

Students need to retrieve information and query materials from the Internet when researching projects. Therefore, the school has set up a search center for the maker workshop, equipped with eight computers to search for information. At the same time, another function of the center is to pay attention to the maker activities carried out by students, publicize the innovative works of students, and promote and publish the information of maker activities on the provincial maker network platform.

\section{- Project Research and Design Office}


A total of four platforms are set up in the project research and design room. The first is an innovative learning platform. The school has specially subscribed to "Invention and Creation," "Juvenile Invention and Innovation," "Middle School Technology," and other magazines. Regularly organize students to read, inspire students' innovative thinking, and lay a good foundation of thinking methods for future innovative activities. The second is a scientific discussion platform. After reading and studying, students combine the problems they have discovered to carry out thought storms and scientific discussions. It puts the wings of perseverance in innovative activities. The third is a collaborative design platform. Based on the first two, students begin to design and plan and put their topics into practice. The fourth is the results display platform. Students develop mature results or works, which are displayed and exchanged here, and provide inspiration and ideas for students to carry out scientific and technological innovation activities in the next stage.

\section{- Production Space}

After studying the student's maker projects, some need to make models or natural objects, and some need hands-on experiments. Therefore, the school is specially equipped with production space, 3D printers, laser cutting machines, digital lathes, and other modern production equipment and tools are all available, creating good conditions for students to practice.

\section{- Robot Studio}

In robot maker education, we combine robot teaching, practical activities, and educational model research. On the one hand, elective courses and club activities are used for teaching, hands-on practice, and competition activities. On the other hand, a research group was established to research the subject of maker education. Thus, the "education + practice + research" model has beneficially promoted students' creative and practical ability.

\section{- Mathematics Inquiry Laboratory}

After high school, a solid geometry laboratory was established, and it was mainly to provide students with a broad and free space through the geometry laboratory. Let each student look at the teacher's design, production, observation, and thinking; then imitate and innovate design and production by themselves. It is similar to a physical and chemical experiment to show the spatial relationship of the research problem by hand to establish accurate spatial concepts and good spatial imagination ability under the comparison of three-dimensional graphics and their corresponding models. Finally, it helps students get convenient and quick problem-solving ideas and methods and improve their ability to analyze and solve problems. Thus, in the teaching process, more practical teaching and learning tools were initially formed. 


\section{- Science Laboratory}

The science laboratory integrates the resources of the school's physics, chemistry, and biology laboratories and adds instruments and equipment for students to carry out innovative and practical activities. Students here mainly complete scientific experiments and scientific investigations related to physics, chemistry, and biology. Emphasize what you have learned, and apply the textbook knowledge you have learned to research and practice. The activities that students carry out here are different from the confirmatory experiments specified in the textbook. Most of the experiments here are based on exploratory experiments.

\section{Following Student Research Projects, an Innovative Curriculum System of “Workshop + Project” Has Been Constructed.}

Based on the resources of the six "workshops," through theoretical research and domestic and foreign comparative research, it integrates various innovative education elements such as scientific disciplines, general technology, scientific and technological invention, innovative design, maker education, mathematical logic, etc. Then four innovative curriculum systems combining "technology and art" have been constructed.

\section{- Disciplinary Integration Curriculum Projects}

This kind, of course, is oriented to apply what they have learned to develop students' subject knowledge and improve their ability to find and ask questions. The system offers four curriculum fusion research projects: research learning, general technology development, mathematical inquiry, and physics inquiry. Research-based education emphasizes basic training and focuses on cultivating student's ability to discover problems. The other three projects focus on developing students to combine the courses they have learned, boost hands-on practical knowledge, learn by doing and do while learning.

\section{- Invention and Creation Course Project}

The invention and creation course is based on the themes of whimsy, exploring science, innovation and creativity, and hands-on production. The course offers robotics and artificial intelligence courses, innovative education, invention and creativity, intellectual property declaration, water science and technology awards, 3D printing, and laser cutting research projects. Such courses are an effective form of STEAM education to promote maker projects.

\section{- Combination of Technology and Art Projects}


The combination of technology and art promotes the maker education project, which focuses on reflecting the brilliance of technology and the charm of art. Combining the two ingeniously to encourage education makers can cultivate students' practical ability and improve students' artistic taste. The course offers four projects: OM (Olympics of Minds), DI (Destination Imagination), IC (Innovative Design Competition), and Space City Design.

\section{- Logical Reasoning Project}

Suppose creation is the prominent position of the maker as a supplement and improvement to the cultivation of creativity. In that case, logical reasoning ability is also the students' ability to find problems and create. Therefore, the school has opened linguistic project research to cultivate students' good thinking chain and provide academic support for maker courses.

\section{Establish the Implementation Plan of "Workshop + Project” to Promote Innovative Education Courses}

In addition to the construction of venues and resources, how to actively and effectively promote is the critical point of the school. Based on the basic situation of school development, the school has independently developed two textbooks, Into Research Learning and I Grow with Innovation. Become a school-based innovative education textbook for students to learn and cultivate students' sense of innovation.

In addition, the school is guided by the cultivation of ability and innovative spirit and progresses step by step per primary, developmental, and specialty goals. And establish three steps (popularity, development, and specialty) $\underline{\underline{I}}$ to normalize, institutionalize and standardize innovative education.

At the same time, the school included maker education as a characteristic project in the school's three-year development plan and included innovative courses in the curriculum. In the course teaching, the "Research Learning Course Plan and Research Progress Manual" is used as the "homework" to set up full-time teachers for research learning and innovative education. Full-time teachers are responsible for course teaching, management, evaluation, and research to ensure the normal development of maker courses.

In the form of a teaching organization, the school is student-oriented and requires all students to participate. In the first semester of grade 10, research courses are offered. Students learn the basic methods of project research, research procedures, and fundamental theories on choosing research projects. Based on general education training based on research learning, the basic knowledge of various courses of students is closely combined to realize the popularization of innovative classes.

Starting from the next semester of the 10th grade, students will be organized into different project research groups according to their hobbies and expertise. From the invention creative project group, water technology invention creative project group, 
OM activity invention creative project group, DI activity invention creative project group, space city design invention creative project group, 3D printing, laser cutting invention creative project group, IC activity invention creative project group, the robot maker research team, and the mathematics exploration project team choose one of the ten projects as their research projects. Three to five people voluntarily combine into groups and complete their research projects in different maker workshops under the guidance of teachers.

The following is an example of the creative education project group curriculum plan, the school's innovative education curriculum promotion plan.

Project purpose: Through innovative education, intellectual property education, enlightenment of thinking, apply what you have learned, creatively solve problems, and cultivate students' practical ability.

Course promotion process:

Section I. Lecture.

Section II. I grow up with innovation courses (The Conjecture of Xiangsha, The Truth About Ghost Face Spider Party), watch the video: My Creative Ideas CCTV "Wonderful Thoughts," "Open Sesame," "Approaching Science. ${ }^{, 2}$

Section III. Scientific seminars, research topics are determined, and research plans are made.

Section IV. Preliminary design activities.

Section V. Production activity class.

Section VI. Read magazine classes "Invention and Innovation," "Juvenile Invention and Creation," and "Technology for Middle School Students."

Section VII. Research and production activities.

Section VIII. Computer retrieval lesson report.

Section IX. Everyone writes the experience of participating in innovative activities this semester.

Section X. Speech at the Innovation Forum.

Section XI. Appraisal and display of research results, patent application, participation in competitions, etc.

\section{Constructed an Evaluation Strategy for the Implemen- tation Effect of Innovative Courses}


The implementation effect of innovative courses needs to be judged through scientific evaluation. At present, curriculum evaluation is based on multiple intelligence theory, focusing on student development and growth in various dimensions (He \& Yang, 2017; Huang \& Hu, 2003). Therefore, schools need to take student development as the core, design an evaluation system in multiple dimensions, and then periodically analyze and evaluate the implementation of innovative courses and the development of students. Then adjust the course content, improve teaching management and form a mechanism for continuous curriculum innovation. At the same time, various awards are set up, and multiple ways to display results are explored to stimulate students' creative enthusiasm (Table 2).

\section{- Scientific Design Evaluation Dimension}

Under the guidance of evaluation goals, the practical evaluation must be based on rich evaluation content. Innovative courses take student development as the core and focus on cultivating students' comprehensive abilities. Therefore, the evaluation dimension is also based on the development of students. As a result, the evaluation content is refined; through the process, students' enthusiasm to participate in different stages of the activity is stimulated.

\section{- Set Evaluation Awards}

Under the guidance of the evaluation target and combined with the evaluation content, the school has established various awards. The staged chain appraisal method is adopted to mobilize students' enthusiasm to participate in the appraisal and display, thereby making the assessment more humane. The awards are divided into the best combination group, the most creative group, the outstanding research and presentation group, the outstanding research group, the best participation award, and the innovation competition achievement award. Through a variety of trophies, students are encouraged to participate and explore actively.

\section{- Expansion of Ways to Display and Recognize Inno- vation Achievements}

Regarding the achievements of students in innovative projects and research activities, on the one hand, the school commends outstanding research results through the school's "science festival." On the other hand, the school uses various channels to identify its achievements to encourage students' creativity.

(i) Publication in Newspapers and Magazines.

The outstanding research results of the students have been carefully revised and perfected by the instructor and recommended by the instructor for publication in relevant newspapers and magazines. 


\section{Table 2. Awards and Assessment Methods.}

\begin{tabular}{|c|c|}
\hline Award & Assessment Method \\
\hline $\begin{array}{l}\text { The Best } \\
\text { Combination } \\
\text { Group }\end{array}$ & $\begin{array}{l}\text { At the beginning of the activity, the students were freely divided into groups, filled } \\
\text { out relevant forms. Then, each group member introduced the reason for joining } \\
\text { the group and jointly formulated the group's goals. After the project activities are } \\
\text { over, the "best combination group" will be selected according to the situation of } \\
\text { each group. }\end{array}$ \\
\hline $\begin{array}{l}\text { The Most } \\
\text { Creative } \\
\text { Group }\end{array}$ & $\begin{array}{l}\text { To mobilize students' enthusiasm to ask questions and cultivate students' ability } \\
\text { to observe and propose topics, each group member is required to present a } \\
\text { maker research project. Then each group selects a project to participate in the } \\
\text { class "The Most Creative Research" competition. }\end{array}$ \\
\hline $\begin{array}{l}\text { Excellent } \\
\text { Research and } \\
\text { Display } \\
\text { Group }\end{array}$ & $\begin{array}{l}\text { Organize presentations and display them in the last class of the semester. Let } \\
\text { the students show their research results in various forms such as slides, models, } \\
\text { speeches, and performances. The school organizes relevant teachers and stu- } \\
\text { dent group leaders to participate in the appraisal and finally selects the "Excel- } \\
\text { lent Research and Display Group." }\end{array}$ \\
\hline $\begin{array}{l}\text { Outstanding } \\
\text { Research } \\
\text { Group }\end{array}$ & $\begin{array}{l}\text { The group can identify and explore topics, topics, and issues of its own choice; it } \\
\text { can find, select and select relevant information from the media, reference mate- } \\
\text { rials, and scientific and technological materials, and form a standardized re- } \\
\text { search report for the group. After the instructor's recommendation, the self- } \\
\text { evaluation of the group, and the comprehensive evaluation of the previous peri- } \\
\text { od, the excellent research study group of the class, grade, and school will be } \\
\text { selected. Commends and rewards according to level, and reports and displays to } \\
\text { the teachers and students of the school, and collects excellent research results } \\
\text { into a book. }\end{array}$ \\
\hline $\begin{array}{l}\text { The Best } \\
\text { Participation } \\
\text { Award }\end{array}$ & $\begin{array}{l}\text { After the project research is over, every student needs to provide a research } \\
\text { experience. Therefore, we will compare and display the research experience of } \\
\text { each student and select the best participation award. }\end{array}$ \\
\hline $\begin{array}{l}\text { Innovation } \\
\text { Competition } \\
\text { Achievement } \\
\text { Award }\end{array}$ & $\begin{array}{l}\text { For projects with a specific value and extensive impact, they will be recommend- } \\
\text { ed to participate in various national competitions after being guided by the } \\
\text { teacher and fully demonstrated. If the standards for intellectual property protec- } \\
\text { tion are met, the school will organize students to participate in patent application } \\
\text { work and provide financial support. All topics recommended to participate in the } \\
\text { competition are awarded as "Innovation Competition Achievement Award." The } \\
\text { projects that can be awarded will be commended and rewarded separately by } \\
\text { the school. }\end{array}$ \\
\hline
\end{tabular}

(ii) Declare Intellectual Property Rights.

For projects with relatively good inventions, innovations, and creativity, the school especially sets up an intellectual property declaration project team to do various tasks such as guidance, communication, novelty search, and declaration.

(iii) Participate in Various Innovation Competitions at All Levels.

The school regularly organizes students from various project groups to participate in multiple competitions at all levels, broadens students' horizons in the activities, stimulates the greater desire for innovation and creativity, and mobilizes students' enthusiasm for learning. 


\section{Effect Evaluation and Thinking}

\section{Significantly Enhance the Students' Innovative Ability}

The students' creative ability has been significantly improved through the practical application of the "Workshop + Project" course. The achievements have been remarkable, and a batch of innovative results has been formed. More than 200 students have won first prizes in multiple national, provincial and municipal innovation design competitions, such as the International Youth Innovation Design Competition, the Asia-Pacific Innovation, and Creativity Competition Beijing Invitational, the World Mind Olympic Innovation Competition China Selection Competition, and the National Linguistics Olympiad. In addition, the research results of 8 students have obtained the patent certificate issued by the State Intellectual Property Office, and many of the research results of the students have been published in the Da He Daily and Invention and Innovation magazines. Furthermore, a study on Plant Ink by eight students, including Jiajia Sun, was included and indexed in CNKI.

\section{Promote the Professional Development of Teachers}

British curriculum scientist Denis Lawton believes that three factors affect the professional development of teachers: changes in technology, changes in teaching ideas, and changes in teaching content (Lawton, 2012). The practice and application process of the "Workshop + Project" course is also the teacher professional development process. During the implementation of the school-based curriculum, all teachers will learn to learn, learn to practice, learn to think, learn to reflect, learn to innovate to become practical researchers, and promote the professional growth of teachers. With the maturity of the innovative curriculum system, teachers have also achieved fruitful results in professional development.

Hongxun Zhang's research results were published in several journals such as Comprehensive Practice Activity Research, Invention and Innovation, and Environmental Education. In addition, Hongxun Zhang published the monograph I Grow Together with Innovation and won the first prize in the National Comprehensive Practice Activity Quality Class Competition, which influenced and led a group of teachers to participate. Hongxun Zhang was also invited to report on the "National Training Program Teacher Training Class" undertaken by the School of Physics and Optoelectronics of Henan Normal University in 2014, 2015, 2016, and 2017.

\section{Promoted the Deepening of School Curriculum Reform}

A school-based curriculum is a school-based curriculum formed by all teachers and students based on its own "individual" development needs under the basic premise of ensuring the overall quality of national education. The "Workshop + Project" course combines innovative education courses with regular subject courses and comprehensive 
practical activities. Arrange creative education courses into the class schedule so that innovative education courses will be implemented as usual. It stimulated the school's curriculum vitality, innovated the school's curriculum structure, formed a new curriculum culture, and promoted school curriculum reform.

\section{Strengthen the School's Characteristics and Improve the School's Teaching Efficiency}

The "Workshop + Project" school-based curriculum has made a distinctive mark for the school. The school's comprehensive school-running benefits continue to show up, forming a certain degree of influence in society. It has been reported by nearly 100 media such as the Chinese Journal of Education, Basic Education Reference, Da He Daily, Zhengzhou Daily, and Zhengzhou TV Station. In 2017, the school successively won a series of honorary titles such as the National Pilot School of Intellectual Property Education for Primary and Secondary Schools, the 3D Printing Demonstration Base of the University of Science and Technology of China, the first advanced research learning school in Zhengzhou, and the Zhengzhou Maker Education Demonstration School.

At the same time, due to the school's distinctive characteristics and significant practical effects, it has formed a greater influence and demonstration effect in the city and even in the province. It has been successfully adopted by Zhengzhou No. 7 Middle School, No. 31 Middle School, and No. 47 Middle School, and has produced noticeable results in these practice test units. In addition, the critical teacher training conferences and technical design and innovation seminars of Henan Province's comprehensive practical activities were held in our school.

Notes

1. Specialty training purpose: Take specialty development and focus on cultivating those with innovative potential and intense interest.

2. "Wonderful Thoughts, " "Open Sesame," and "Get Closer to Science" are all popular science $T V$ programs launched by China Central Television. The first two are popular science programs for children established for 7-14 years old students. 


\section{References}

Guo, H. (2000). An analysis of the status quo of innovative education in classroom teaching in critical middle schools. Modern Education Science, 13(6):13-15.

[Chinese] DOI:

https://doi.org/10.13980/j.cnki.xdjykx.gjy j.2000.06.004

Hallinen, J. (2020, July 15). STEM. Encyclopedia Britannica. Retrieved June 25, 2021 from

https://www.britannica.com/topic/STEMeducation

He, K. (2016). On Maker Education and Innovation Education. Educational Research, 23(4):12-24+40. [Chinese] http://www.cnki.com.cn/article/cjfdtotaljyyj201604003.htm

He, X., \& Yang, D. (2017). Discussion on school curriculum evaluation strategies based on the development of students' core literacy. Contemporary Education Sciences, 31(10):18-22. [Chinese] DOI: https://doi.org/10.3969/j.issn.16722221.2017.10.005

Huang, L., \& Hu, Z. (2003). Multiple intelligence theory and curriculum evaluation. Curriculum, Teaching Material and Method, 23(5):15-18. [Chinese] DOI: https://doi.org/10.19877/j.cnki.kcjcjf.2003 .05 .005

Kalil, T. (January 12, 2015). A new resource for bringing making into education. The White House, President Barack Obama. Retrieved June 30, 2021 from https://obamawhitehouse.archives.gov/blo g/2015/01/12/new-resource-bringingmaking-education

Lawton, D. (2012). Theory and practice of curriculum studies. Routledge.

Li, W., \& Wang, J. (2014). On the construction of a high school innovative education system. Theory and Practice of Contemporary Education, 6(6):18-20. [Chinese] DOI:

https://doi.org/10.13582/j.cnki.16745884.2014.06.042

Maslyk, J. (October 30, 2018). These are the students who benefit from Maker Educa- tion. Demco. Retrieved June 30, 2021

from

https://ideas.demco.com/blog/maker-

education-student-

benefits/?sfw=pass 1625299489

Office of the Press Secretary. (November 23, 2009). President Obama launches the "Educate to Innovate" campaign for excellence in Science, Technology, and Engineering \& Math (STEM) education. The White House, President Barack Obama. Retrieved June 30, 2021 from https://obamawhitehouse.archives.gov/the -press-office/president-obama-launcheseducate-innovate-campaign-excellencescience-technology-en

Schumpeter, J.A. (1934) The Theory of Economic Development: An Inquiry into Profits, Capital, Credits, Interest, and the Business Cycle. Transaction Publishers, Piscataway.

Shapiro, P. (October 30, 2016). Learning by making is more humane. Retrieved June 30, 2021 from https://makezine.com/2014/01/22/learning -by-making-is-more-humane/

Teng, J., Yan, Z., Zhang, M., \& Duan, Y. (2019). Analysis of STEM education and maker education. Modern Educational Technology, 26(11):101-106. [Chinese] http://www.cnki.com.cn/Article/CJFDTot al-XJJS201911016.htm

The Ministry of Education of the People's Republic of China, MOE. (January 5, 2018) Notice of the Ministry of Education on printing and distributing the "General High School Curriculum Program and Chinese and Other Subject Curriculum Standards (2017 Edition)" (Textbook [2017] No. 7). Retrieved June 1, 2021, from the Website of Ministry of Education of PR

http://www.moe.gov.cn/srcsite/A26/s8001 1201801/t20180115_324647.html [Chinese]

The Ministry of Education of the People's Republic of China, MOE. (January 05, 2018). General Technical Curriculum 
Standards for General High Schools. Retrieved June 15, 2021 from

http://www.moe.gov.cn/srcsite/A26/s8001 /201801/t20180115_324647.html [Chinese]

The Ministry of Education of the People's Republic of China, MOE. (June 7, 2016). Notice of the Ministry of Education on printing and distributing the "Thirteenth Five-Year Plan for Education Informatization" (Jiao Ji [2016] No. 2). Retrieved July 1, 2021, from http://www.moe.gov.cn/srcsite/A16/s3342 1201606/t20160622_269367.html [Chinese]

The Office of the Working Group of the National Medium and Long-term Education
Reform and Development Plan Outline. (July 29, 2010) The National Medium and Long-term Education Reform and Development Plan Outline (2010-2020). Retrieved July 1, 2021, from

http://www.moe.gov.cn/srcsite/A01/s7048 /201007/t20100729_171904.html [Chinese]

Yang, G. (2016). Maker education: a new path for the development of innovative education in my country. China Educational Technology, 23(3):8-13+20. [Chinese] DOI:

https://doi.org/10.3969/j.issn.1006$\underline{9860.2016 .03 .002}$

Received: 06 July 2021

Revised: 11 August 2021

Accepted: 11 August 2021 